\title{
Jornal $\boldsymbol{A}$ Luta e a crítica da prática jornalística em $1952^{1}$
}

\author{
Nilsângela Cardoso LIMA² \\ Kamilo Carvalho de ALMEIDA ${ }^{3}$
}

\begin{abstract}
Resumo:
O presente trabalho propõe um estudo sobre o jornal $A$ Luta, em especial, a produção discursiva acerca da modernização da imprensa e da prática jornalística no Piauí. Adotando a análise foucaultiana do discurso como ferramenta teórica e metodológica de pesquisa, selecionaram-se as matérias autorreferenciais de $A$ Luta, no ano de 1952, que discorrem sobre o jornalismo moderno e os mecanismos de controle da produção da notícia, que se pretende imparcial e apartidária. Assim, verificou-se que A Luta instituía valores, competências e regras do jornalismo moderno para a sua redação por meio do discurso autorreferencial, que diz respeito à crítica das práticas, à defesa do apartidarismo da linha editorial para os leitores e, particularmente, os mecanismos de controle da produção discursiva que desejavam colocar em prática.
\end{abstract}

Palavras-chave: jornalismo; prática jornalística; discurso autorreferencial; A Luta.

\section{A Luta newspaper and the critique of the journalistic practice in 1952}

\begin{abstract}
:
This paper proposes a study about A Luta newspaper, in particular, its discursive production about the modernization of press and the journalistic practice in Piauí. Adopting Foucault's Discourse Analysis as theoretical and methodological research tool, we selected A Luta self-referential articles from 1952 that discuss about the modern journalism and the control mechanisms of news production, which intends to be impartial and nonpartisan. Thus, we verified that A Luta instituted modern journalism values, competences and rules for its editorial department through the self-referential discourse, which concerns to the criticism of practices the defense of the nonpartisan editorial line for the readers and, particularly, the control mechanisms of discursive production which they intended to put into practice.
\end{abstract}

Keywords: journalism; journalistic practice; self-referential discourse; A Luta.

\section{Periódico $\boldsymbol{A}$ Luta y la crítica de la práctica periodística en 1952}

Resumen:

El presente trabajo propone un estudio sobre el periódico A Luta, en particular, la producción discursiva acerca de la modernización de la prensa y la práctica periodística en Piauí. Adoptando el análisis del discurso propuesto por Foucault como herramienta de investigación teórica y metodológica, fueron elegidos los artículos

\footnotetext{
${ }^{1} \mathrm{O}$ presente texto é uma versão modificada do que foi publicado nos Anais XII Encontro Nacional de História da Mídia, 2019. O trabalho conquistou o primeiro lugar do Prêmio José Marques de Melo.

2 Doutora, professora do Curso de Comunicação Social-Jornalismo e do Programa de Pós-Graduação em Comunicação da Universidade Federal do Piauí. E-mail: nilsangelacardoso@ufpi.edu.br.

3 Graduando do Curso de Comunicação Social - Jornalismo da Universidade Federal do Piauí. E-mail: kamilocarvalho@hotmail.com.
} 
autorreferenciales de $A$ Luta, en el año 1952, que tratan sobre el periodismo moderno y los mecanismos de control de la producción de noticia que se pretende ser imparcial y apartidista. Así, se verificó que $A$ Luta instituyó valores, competencias y reglas del periodismo moderno para su redacción a través del discurso autorreferencial, que concierne a la crítica de las prácticas, la defensa del apartidismo en la línea editorial para los lectores y, en particular, los mecanismos de control de la producción discursiva que deseaban poner en práctica.

Palabras clave: periodismo; practica periodística; discurso autorreferencial; A Luta.

\section{Introdução}

A emergência do jornalismo pautado na informação e na objetividade é proveniente do século XIX. A afirmativa é verdadeira em parte, posto que é válida somente para algumas regiões do globo terrestre, a exemplo dos Estados Unidos e uma parte da Europa, que viu surgir nesse período o novo jornalismo, denominado pennypress. De acordo com Traquina (2005), esse novo modelo de jornalismo foi acompanhado por uma série de mudanças políticas, econômicas, sociais e culturais pelas quais esses países passaram, dentre elas: a comercialização da imprensa, a profissionalização dos jornalistas, o desenvolvimento do sistema econômico, a industrialização, os avanços tecnológicos, a educação, a urbanização das cidades, etc.

Tais fatores contribuíram significativamente para a expansão da imprensa e seu processo de despolitização nos Estados Unidos e em parte da Europa no século XIX. Conforme Traquina (2005), à medida que os jornais adquiriam outra fonte de renda, como a publicidade, afirmavam sua independência em relação aos partidos políticos, implicando diretamente nas mudanças das práticas jornalísticas pautadas na opinião e na propaganda ideológica. O modelo de jornalismo pennypress passava, gradativamente, a ser um novo imperativo nas redações e a notícia ganhava status de um novo produto: a informação como mercadoria.

Enquanto nos Estados Unidos e na Europa o processo de despolitização da imprensa e do jornalismo encontrava-se a passos acelerados no século XIX, no Brasil, foi um pouco mais tardio. ${ }^{4}$ É somente no início dos anos 1800 que se registra a chegada da Imprensa Régia, que tinha por finalidade imprimir atos oficiais e assuntos de interesse da coroa portuguesa, e o surgimento do primeiro jornal impresso no país, denominado Gazeta do Rio de Janeiro, em 10 de setembro de 1808 .

\footnotetext{
${ }^{4}$ Sobre as três correntes teóricas que explicam a chegada tardia da imprensa brasileira, ver Melo (1973).
} 
Durante todo o período colonial brasileiro, a imprensa esteve vinculada aos grupos de poder político e econômico. Esse quadro que perdura durante o Império (1822-1889), quando os jornais estavam condicionados aos interesses econômicos, políticos e intelectuais dos grupos familiares que os financiavam e se diferenciavam pela filiação ideológica de cada um em liberal, conservador e/ou abolicionista. Para Martins (2011), embora a imprensa fosse utilizada como demarcadora de posições e lutas das famílias de poder na Província, o período foi importante para ensaiar algumas das transformações que se tornariam mais notáveis no jornalismo do século XX.

A imprensa e o jornalismo brasileiros ganham nova feição no século XX. É na passagem da imprensa artesanal para a industrial que métodos racionais são cada vez mais empregados nos modos de produzir notícias. Conforme Luca (2011), o modelo de "jornal-tribuna” começava a perder espaço para o de "imprensa-empresa", sustentado pela ideia de jornalismo enquanto "espelho da realidade" e portador da verdade. No entanto, assinala a autora, embora os jornais adentrassem ao mundo dos negócios, eles continuavam se constituindo “[...] em espaço privilegiado de luta simbólica, por meio do qual diferentes segmentos digladiavam-se em prol de seus interesses e interpretações de mundo" (LUCA, 2011, p. 158) e o matiz ideológico ainda era visto como um fator de diferenciação entre órgãos.

Até 1940, como demonstra Ribeiro (2003), a maioria dos jornais no Brasil era instrumento político. Realidade que começa a mudar nos anos 1950, com a substituição do jornalismo político-literário pelo empresarial e a adoção do modelo de jornalismo norteamericano. A partir de então, impunha-se um jornalismo moderno, no qual a informação, a neutralidade e a objetividade deveriam ser seguidas à risca. A fim de que os jornais e os jornalistas abandonassem as velhas práticas de produção pautadas na linguagem virulenta, pessoal, adjetivada, foram estabelecidas novas técnicas de redação que exigiam uma nova estruturação da linguagem e feição gráfica.

Em Teresina, capital do Piauí, tais práticas e mudanças na imprensa e no jornalismo não foram diferentes. Nesse sentido, o trabalho apresenta um estudo sobre o jornal A Luta, publicado em 1952, momento em que praticamente todos os jornais de Teresina buscavam se mostrar modernos e imparciais, por meio de matérias autorreferenciais. O jornal teve vida efêmera, contudo, durante os quatro meses em que circulou, fez questão de afirmar o apartidarismo da 
sua linha editorial para os leitores, particularmente, quando se definia como órgão de orientação independente, noticioso e informativo.

O jornal A Luta teve doze edições publicadas, porém, apenas nove delas foram localizadas no Arquivo Público do Estado do Piauí. As nove edições compõem o corpus da pesquisa. Para realizar o estudo, foi adotada a análise foucaultiana do discurso como ferramenta teórica e metodológica da pesquisa. Partindo dos conceitos de discurso, prática discursiva e formação discursiva, Foucault (1999) possibilita chaves para analisar os discursos jornalísticos e os procedimentos de controle em determinado contexto e tempo histórico.

De acordo com Foucault $(1999$, p. 8), “[...] em toda sociedade a produção do discurso é ao mesmo tempo controlada, selecionada, organizada e redistribuída por certo número de procedimentos $[. .$.$] ”' externos e internos. Noção que ganha amplitude teórica e metodológica na$ obra Arqueologia do saber, na qual Foucault (2010, p. 132) dá um sentido pleno ao conceito, definindo o discurso como um conjunto de enunciados que se apoiam numa mesma formação discursiva; ou seja, o discurso é "constituído de um número limitado de enunciados para os quais podemos definir um conjunto de condições de existência". Considerando que todo o discurso é histórico e corresponde às transformações e aos modos específicos de sua temporalidade, o autor define prática discursiva como um conjunto de regras anônimas determinadas pelas condições de exercício da função enunciativa (FOUCAULT, 2010).

A proposição teórica e metodológica de Foucault $(1999,2010)$ é utilizada na medida em que se pretende entender como, em determinado contexto histórico, os discursos produzidos pelo jornal A Luta buscaram instituir competências jornalísticas e regulamentos para a sua redação, tendo como parâmetro o modelo de jornalismo moderno. Por meio do discurso materializado nas páginas de $A$ Luta, é possível encontrar indícios da cultura jornalística e dos regulamentos/mecanismos postos em prática na imprensa de Teresina no início dos anos 1950 .

Para Traquina (2008, p. 46), “o jornalismo é também uma prática discursiva” e os profissionais do campo partilham uma cultura noticiosa comum. Partindo da concepção da notícia como uma construção social, o autor aponta que ela é resultado das interações dos diferentes agentes que reivindicam um conjunto de competências para o fornecimento da informação. Nessa busca, os jornalistas buscam definir os valores, as regras e uma identidade profissional para atuarem como "servidores do público". 
No século XX, a ideologia da objetividade e a fidelidade às regras não só passa a ser o novo código da produção de notícias, como também contribuiu para a definição de como "deve ser o jornalista" e "estar no jornalismo". Para Traquina (2008, p. 23), "as notícias refletem um ethos especializado da comunidade jornalística e são moldadas por suas estruturas e processos". Dessa forma, com a emergência do novo paradigma jornalístico baseado na informação e não na propaganda, os jornalistas reivindicam um monopólio do saber e professam como as notícias devem ser escritas, em particular, no que toca às questões sobre a responsabilidade do jornalista, os preceitos éticos da profissão, limites da liberdade de imprensa e outras características do campo.

De acordo com Traquina (2005, p. 121, grifos do autor), “[...] a vasta cultura profissional dos jornalistas fornece um modo de ser/estar, um modo de agir, um modo de falar, e um modo de ver o mundo [...]". Assim, considerando que, em 1952, o jornal A Luta não contava com um código deontológico explícito, as regras, os valores, as competências eram instauradas pelos próprios jornalistas por meio do discurso. Algumas dessas regras ficaram materializadas nas páginas das edições analisadas de $A$ Luta, sendo expostas como padrões indispensáveis aos profissionais que buscavam acompanhar e instituir técnicas modernas do jornalismo.

\section{Imprensa piauiense e o jornal $\boldsymbol{A}$ Luta}

No Piauí, as primeiras tipografias apareceram na primeira metade do século XIX e surgiam como "lentes políticas" dos partidos e grupos familiares que as financiavam (RÊGO, 2001). Em 1832, nascia O Piauiense, considerado o primeiro jornal da Província. O impresso era editado na Tipografia de Silveira \& Cia e restringia-se a publicar atos do Governo provincial e de outros órgãos oficiais.

Apesar de $O$ Piauiense caracterizar-se como órgão oficial do governo provincial, é somente com o surgimento de $O$ Telégrafo, em 1839, que “[...] o caráter político assume, definitivamente, a sua posição dentro do jornalismo" (RÊGO, 2003, p. 3). O jornal era financiado pelo governador Manuel de Sousa Martins, conhecido como "Barão da Parnaíba", e destinado a fazer a defesa do seu governo, em especial, durante a Balaiada no Piaúi (PINHEIRO FILHO, 1996). 
Os dois primeiros órgãos de imprensa que surgiram na Província do Piauí apontam que, desde o início, os jornais mantinham ligações estreitas com os grupos de poder político e econômico. Característica que se observa durante o século XIX e boa parte do século XX, quando os jornais eram mantidos a serviço dos partidos políticos e usados como porta-vozes. Segundo Pinheiro Filho (1996, p. 163), Anísio Brito teria afirmado que, até a primeira metade do século XX, os jornais no Piauí surgiam e desapareciam “[...] ao saber das mutações políticas, e, ou são folhas de duração efêmera, ou de partidos, constituindo-se os lugares da imprensa, verdadeiros meios para se galgarem os altos e pequenos postos da administração, ou da política".

Pinheiro Filho (1996) ainda destaca que, em meados do século XX, Teresina e outros municípios do Piauí estavam perdendo suas características de "aldeia". Porém, desde o fim do Estado Novo, o Piauí, assim como todo o resto do país, voltava para um período de "normalidade política tradicional, ou seja: lutas pessoais, retaliações, corrupção generalizada, fraudes eleitorais" (PINHEIRO FILHO, 1996, p. 201). Com a criação dos partidos nacionais, em 1945, o Partido Social Democrático (PSD), a União Democrática Nacional (UDN) e o Partido Trabalhista Brasileiro (PTB) eram os maiores partidos do Piauí e mantinham jornais à sua disposição. Lima (2014) explica que os embates entre os dois partidos e seus correligionários aconteciam pela imprensa da época que, transformada em tribuna, atuava como instrumento de luta partidária pelo poder político.

Nos anos 1950, na capital piauiense, os jornais até se declaravam no expediente ou por meio de matérias autorreferenciais como independentes, informativos e noticiosos (LIMA, 2014). Mas, na prática, continuavam produzindo e publicando discursos opinativos e, por vezes, combativos, virulentos, visto que nem todos abdicaram da posição partidária e ideológica e do jornalismo doutrinário para relatar os fatos.

No tocante ao jornal A Luta, foi encontrado um conjunto de matérias autorreferenciais que discorrem sobre a crítica das práticas jornalísticas e a constelação de valores que os jornalistas pretendiam reforçar e/ou excluir. Em Teresina, o discurso autorreferencial em matérias jornalísticas foi uma estratégia utilizada pelos profissionais do campo para estabelecer competências jornalísticas e mecanismos de controle da produção discursiva que desejavam colocar em prática, sobretudo, para firmarem-se como imparciais e modernos. 
Por autorreferencialidade na mídia, Fausto Neto (2006) entende a competência discursiva que os dispositivos midiáticos usam para falar de si mesmos e dos outros campos sociais em contextos históricos específicos. Para Fausto Neto (2006, p. 6), é por meio do discurso autorreferencial que a mídia institui a realidade que constrói, “[...] oferecendo suas lógicas e elementos de sua 'cultura' para que se possa gerir novos processos e operações de inteligibilidade social".

Ao discorrer sobre as estratégias de negociação da autoridade jornalística no espaço social, Lopes (2007) considera que é bastante comum os jornalistas utilizarem o espaço da mídia para se autorreferenciarem. Geralmente, o jornalista se autorreferencia para reforçar valores, expor aspectos de sua identidade, caracterizar assuntos relativos ao interior da redação, mostrar elementos da cultura jornalística que acredita ser relevantes e se apresentar para a sociedade como detentor de poder de fala. Por isso, o discurso autorreferencial nas matérias jornalísticas é " [...] local estratégico em que os atores buscam um consenso provisório sobre suas competências típicas e sua autoridade" (LOPES, 2007, p. 3).

Tal postura pode ser observada no jornal A Luta, que surgiu em 29 de julho de 1952 pelos fundadores da Empresa Gráfica Editora 'A Luta' S.A.. Na sua primeira edição, o jornal publicou o programa do órgão, definindo-se como de orientação "independente, noticiosa e informativa" e ainda se caracterizando desse modo: "Este órgão não está a serviço de nenhuma agremiação partidária do Estado ou fora dele, uma vez que os partidos políticos transpõem a orbita de sua legítima ação toda vez que pretendam contrariar a expressão da justiça, da verdade e do direito" (PROGRAMA, 1952, p. 1).

Apresentar-se ao seu leitor como independente e imparcial foi uma das primeiras estratégias adotadas pela direção e redação do jornal $A$ Luta e isso não acontecia por acaso. No período analisado, os órgãos de imprensa, cada vez mais, buscavam declarar a independência da linha editorial em relação à ideologia partidária para afirmar-se como imparciais e modernos, portanto, distantes do jornalismo doutrinário.

Contudo, ainda que no Programa do órgão constasse o juramento da independência da linha editorial em relação aos partidos políticos, nele, a direção e a redação também confessaram: "Não somos neutros. Somos imparciais". A declaração conduz a pensar que a despeito de o jornal se autodefinir como informativo e noticioso, não deixaria a opinião de lado. 
De acordo com Melo (1985, p. 15), “[...] a distinção entre a categoria informativa e a opinativa corresponde a um artifício profissional e também político", de maneira que as duas categorias não possuem barreiras intransponíveis, por mais que recorram aos artifícios da linguagem. Ainda conforme o autor, historicamente, entende-se que o objetivo do jornalismo informativo é relatar os fatos, enquanto o do jornalismo opinativo é expressar as ideias. Porém, ao relatar um fato, a instituição jornalística também busca influenciar seus leitores e cada processo jornalístico tem sua dimensão ideológica.

A interação entre as duas categorias, para Melo (1985, p. 18), torna-se ainda mais transparente quando "a instituição jornalística assume o papel de observadora atenta da realidade", cabendo ao jornalista atuar como "vigia" para registrar e informar os fatos à sociedade, o que corresponderia ao jornalismo informativo. Todavia, também cabe ao jornalista reagir, difundir/formar opiniões e atuar como "conselheiro", função que compete ao jornalismo opinativo.

Na década de 1950, em conformidade com Lima (2014), os jornais de Teresina se autodeclaravam como vigilantes do poder público, competindo ao jornalista o papel de informar, orientar e formar a opinião pública de forma honesta, sensata e justa, tendo como princípio a verdade e a ética jornalística. Por esse ângulo, na segunda edição de A Luta, de 6 de julho de 1952, esses elementos da cultura jornalística aparecem em pelo menos duas oportunidades no material analisado. Primeiro, na matéria intitulada "O jornalista", na qual Lino Corrêa Lima ressalta que o órgão tinha o "sagrado mandato de defensor do povo e das instituições", e seus jornalistas, no cumprimento dos valores morais e espirituais, deveriam manter a vigilância permanente na busca de justiça contra aqueles que lutam para esmagar o povo. Segundo, no editorial "Conversa", em que a direção de A Luta aponta que tem entrado em entendimentos com agências noticiosas no intuito de oferecer um amplo material informativo, bem como prometia fazer uma imprensa "sadia", "honesta" e "imparcial" (CONVERSA, 1952, p. 1).

As marcas do jornalismo moderno, clamadas por A Luta, apareceram nos discursos que salientavam o esforço da redação e direção de oferecerem ao leitor seções de interesses gerais, variedades de informações, linguagem comedida, feição gráfica e paginação modernas. A própria promessa do diretor de manter em circulação um "veículo moderno de cultura e 
educação", amparada no conceito de uma imprensa "sadia" e "honesta", pode ser analisada como um "ritual estratégico" para afirmar a imparcialidade defendida pelo órgão (CONVERSA, 1952, p. 1).

Por exemplo, o termo "imprensa sadia" revela uma tentativa da direção de se diferenciar dos demais jornais, que, presos ao modelo de jornalismo opinativo, político e combativo empregavam uma linguagem virulenta e prenhe de xingamentos. E o termo "honesta" descamba na ideia de uma imprensa veiculadora da verdade e de um jornalismo pautado nos padrões modernos de imparcialidade e de objetividade, já idealizados pelos jornalistas brasileiros e piauienses dos anos 1950 .

Como expõe Traquina (2005), na busca do valor verdade e da objetividade, os jornalistas pregaram a honestidade e a justeza como um dever deles para com os leitores. Frequentemente, o rigor, a exatidão e a honestidade foram alçados a conceito de objetividade no jornalismo, que "não é uma negação da subjetividade, mas uma série de procedimentos que os membros da comunidade interpretativa utilizam para assegurar uma credibilidade como parte nãointeressada e se protegerem contra eventuais críticas ao seu trabalho" (TRAQUINA, 2005, p. 139). Em outras palavras, é um "ritual estratégico" invocado pelos jornalistas para neutralizar potenciais críticas.

No que diz respeito à linguagem empregada pela sua redação, na seção "Ecos", de 13 de julho de 1952, o jornal destaca que tem sido bem recebido pelo público e que cumpriria a tarefa de reformar a mentalidade jornalística de Teresina, nomeadamente, por não fazer uso de uma linguagem injuriosa e virulenta:

[...] o jornal dirigido por A. Tito Filho há de cumprir o alto desígnio de reformar a mentalidade jornalística de nossa terra, pois nele não encontrarão guarida jamais artigos e notas escritas em linguajar de tropeiros e cafagestes. Mesmo que cheguemos a apontar falhas e êrros da administração pública e comentários em torno de atitudes dos nossos homens públicos, temos o propósito de nunca usar têrmos de baixo calão, pois, as injúrias só podem causar acirramentos de ódios e prevenções pessoais. Nossas críticas hão de ter sempre a preocupação de bem servir à coletividade e concorrer para a reforma dos nossos costumes políticos (ECOS, 1952a, p. 3).

Foucault (1999) explica que todo discurso tem seu polo de produção e obedece aos interesses das instâncias e das relações de poder que o produz. Desse modo, o jornal reforçava 
que a função dos redatores de $A$ Luta era servir à coletividade e reformar os costumes políticos do Piauí. Assunto que foi novamente pautado na seção "Ecos", de 23 de agosto de 1952, na qual a redação alega que se dispõe "[...] a lutar pelas reivindicações mais justas e sentidas do povo piauiense e a mostrar os erros de todos aqueles que exercem qualquer função pública em nossa terra" (ECOS, 1952b, p. 3). Observa-se que o jornal se dispõe a condenar o erro de "todos" os homens públicos, o que denota as marcas da imparcialidade discursivamente defendida para a sua linha editorial.

A imparcialidade tão defendida pela redação de $A$ Luta aparece em outras matérias autorreferenciais. Na primeira edição, a direção afiança que não acobertava um partido político, como também pontua que abrigava redatores e colaboradores de diferentes filiações partidárias que, no jornal, “[...] se comprometeram a lutar por um mundo melhor, intransigentemente ao lado dos interesses supelieres [SIC] da coletividade" (PROGRAMA, 1952, p. 1).

Tal autodefesa se fazia pelo conhecimento público da filiação do seu diretor, A. Tito Filho, que, desde 1945, atuava de forma panfletária na imprensa piauiense, inclusive, apoiando a candidatura do brigadeiro Eduardo Gomes e candidatos da União Democrática Nacional (UDN) no Piauí (ASSUNÇÃO, 2009). Não muito diferente, o redator Cunha e Silva participou ativamente de campanhas políticas pela imprensa. Em 1947, Cunha e Silva mantinha ligação com a UDN, mas rompe com o partido ainda na gestão do governador Rocha Furtado (UDN, 1947-1950) e aproxima-se do Partido Social Democrático (PSD), à época, o maior partido de oposição (LIMA, 2014). Já em 1950, tanto o diretor A. Tito Filho quanto o redator Cunha e Silva saíram candidatos a deputado estadual pelo PSD. José Patrício Franco, redator-chefe, foi vereador em Teresina pelo PSD. O nome do redator Valdemar Sandes aparece como um dos participantes da Convenção Estadual do Partido Trabalhista Brasileiro (PTB) (VIDA DOS PARTIDOS, 1952, p. 8).

Em 20 de julho de 1952, mais uma vez, a redação volta a defender a imparcialidade do jornal. Agora, a pauta refere-se à acusação de o jornal ter "o cordão umbilical preso ao governo do Estado", uma vez que é impresso nas oficinas do Diário Oficial (A DIREÇÃO, 1952, p. 8). Em sua defesa, a direção afirma que não obedece a diretrizes de nenhum partido político, nem escreve pasquim, muito menos recebe soldo do governo estadual, de opositores ou de oportunistas. Reitera que embora os seus jornalistas tenham suas convicções partidárias, em $A$ 
Luta, todos eles fazem uma imprensa honesta, moralizadora, sadia, regularizada pelos princípios da razão e da justiça.

\section{Elogios e críticas à redação do jornal $A$ Luta}

Nas edições de 1952 analisadas, pode-se verificar que outra estratégia de A Luta para atribuir a si poder simbólico frente à concorrência com outros órgãos de imprensa existentes em Teresina, na época, foi a de publicar matérias, cartas e/ou notas com elogios e críticas ao jornal. Esse material reúne informações importantes para entender a cultura jornalística de $A$ Luta e alguns dos valores içados como elementares para a sua redação na produção das notícias. Além da opinião dos leitores, há também a resposta da direção de $A$ Luta às críticas/elogios que, ao fazer isso, explanava as regras da sua redação.

Assim como boa parte dos jornais brasileiros, A Luta também reservou um espaço para a publicação das cartas de leitores. Prática muito comum no jornalismo brasileiro de então, quando os impressos buscavam reconhecer o leitor como um sujeito participante ativo no processo de interação através da escrita. De acordo com Crestani (2010), nos anos 1950, a imprensa começou a perceber o leitor não apenas como um mero "receptor", como entendia o modelo circular da comunicação. Ao contrário, o leitor passava a ser visto como sujeito ativo no processo de interação, de modo que "[...] importam não apenas os efeitos da comunicação sobre o receptor, como também os efeitos que a reação do receptor produz sobre o emissor" (BARROS, 2003, p. 42 apud CRESTANI, 2010, p. 36).

No caso de $A$ Luta, a interação acontecia prioritariamente na seção denominada "Correio de A Luta". O leitor mandava uma carta endereçada para a direção, que era publicada na íntegra e, algumas vezes, acompanhada de uma resposta do diretor do órgão, A. Tito Filho. Certamente, nem todas as cartas de leitores enviadas à direção chegaram a ser publicadas. Dentro do processo de seleção do que o jornal tinha interesse de dar visibilidade, há pelo menos duas cartas e respostas que merecem destaque.

A primeira carta transcrita pelo jornal foi publicada na sua terceira edição. Assinada por José Alves de Paula, a missiva contém críticas contundentes ao diretor de A Luta, A. Tito Filho, acusando-o de ter publicado na seção "Ecos", de sua primeira edição, informações descabidas sobre a atuação dos professores em Teresina. José Alves de Paula tanto condena o diretor do 
jornal por advogar pelo uso de armas pelos professores em sala de aula, quanto o acusa de ser alheio aos problemas dos estudantes e da educação. A carta pediu uma resposta ou esclarecimento do jornal sobre sua atuação e seu papel, desencadeando um processo de interação e diálogo maior entre o leitor e o diretor por meio de respostas, réplicas e tréplicas.

Para além do conteúdo das matérias que tratam do problema no ambiente escolar, importa olhar para elementos que apontam para os valores e as regras determinadas para a redação de $A$ Luta, que ficam mais claras na segunda resposta publicada pelo diretor. Por um lado, A. Tito Filho destaca a honestidade do jornal de publicar a carta na íntegra, respeitando todo o conteúdo e conceitos empregados no texto. Por outro, promete ficar atento aos erros de ortografia alegados pelo missivista e sua devida correção nas próximas edições (CORREIO DE “A LUTA”, 1952a, p. 3).

Essa é a única carta publicada acompanhada de uma resposta do diretor de $A$ Luta. As demais cartas não tiveram resposta do diretor, talvez porque uma delas apresentava apenas esclarecimentos pessoais da atuação do político na Câmara e a outra por tecer elogios ao novo jornal que chegava ao Piauí. É o caso da carta de Virmar Soares, do Rio de Janeiro, transcrita na edição de 20 de julho de 1952.

O conteúdo da carta de Virmar Soares refere-se à admiração da leitora à atuação jornalística de A Luta. Segundo ela, o impresso possuía uma feição moderna por meio de uma "paginação inteligente e elegante", com "destaque tipográfico das matérias", bem como se apresentava de forma despretensiosa sem recorrer a manchetes sensacionalistas (CORREIO DE “A LUTA”, 1952b, p. 2). Além disso, Virmar Soares finaliza parabenizando a direção do órgão com destaque para o conteúdo que, em geral, publicava.

Além da seção Correio de "A Luta”, o jornal abrigou em suas colunas outras mensagens parabenizando o seu trabalho. Nem sempre essas mensagens eram de leitores piauienses, mas de correspondentes do jornal no Rio de Janeiro, tal como Antônio Lemos, que destacou os jornalistas que compõem a redação do jornal, a tarefa árdua desempenhada por eles em servir a coletividade e, por último, encorajava a todos na empreitada de combater os erros administrativos.

Outra mensagem nesse sentido aparece na transcrição da matéria publicada pelo jornal Gazeta do Sul, de 13 de julho de 1952. Nela, consta que A Luta apresenta uma feição gráfica 
moderna, inclusive competia com os principais órgãos “Associados do Norte do Brasil”, porém de conteúdo melhor, porque ia "muito além das bozeiras "chatobrianas"” (A LUTA, 1952, p. 3. Esse último aspecto de alguma maneira faz referência à feição política e partidária adotada pelos jornais de Assis Chateaubriand, com o objetivo de diferenciar a postura de A Luta nas lides jornalísticas, que é vista como um órgão independente com "I maiúsculo", um "jornal de vergonha para servir ao Piauí honesto" (A LUTA, 1952, p. 3).

As cartas, matérias e notas da redação reiteram o que a redação e a direção do jornal buscavam definir para a linha editorial de $A$ Luta desde que publicou o seu programa na primeira edição. Mostrar-se como um jornal moderno, sadio, honesto, imparcial e independente foi uma preocupação constante de seus fundadores, reafirmando que seu papel era de defender a coletividade e as instituições sem demagogia e sensacionalismos. De acordo com o jornal, cabia à redação de $A$ Luta criticar e analisar os atos da administração estadual e municipal "com imparcialidade e espírito de justiça" (ECOS, 1952b, p. 3).

Para tanto, defendia o jornal, as críticas aos atos dos homens públicos seriam construídas por meio de uma linguagem decente, comedida e, quando necessário, severa e com expressões mais carregadas, mas sem recorrer às "verrinas" e retaliações pessoais. Em duas edições, a seção "Ecos" foi utilizada pela direção/redação para responder aos leitores sobre a postura do jornal na produção de matérias sobre a vida política e administrativa do Piauí.

Na edição de 23 de agosto de 1952, o jornal esclarece que o diretor e os redatores mantinham-se filiados aos seus respectivos partidos, no entanto, isso não os impedia de uma avaliação imparcial dos fatos políticos. Além disso, o jornal afirma que a direção aceitava publicar quaisquer matérias que tratassem da vida política e administrativa do Piauí, desde que fosse empregada linguagem decente e comedida e esclarecia:

[...] Não agasalhamos, entretanto, em nossas colunas recalques pessoais de quem quer seja e, com decisão e coragem, nos dispomos a lutar pelas reivindicações mais justas e sentidas do povo piauiense e a mostrar os erros de todos aqueles que exercem qualquer função pública em nossa terra. [...] (ECOS, 1952b, p. 3).

\footnotetext{
${ }^{5}$ A expressão "bozeira” utilizada pelo jornal Gazeta do Sul não é definida no corpo da matéria.
} 
Já na edição de 7 de setembro de 1952, A Luta ocupa a seção "Ecos" para responder a um leitor que sugeriu ao jornal atacar o governo por meio do uso de uma linguagem virulenta. Em sua resposta, a redação afirma que esse não é o seu lema e que não há a intenção de mover campanha para algum partido ou político específico, nem dirigir ataques pessoais.

Continúa [sic] o nosso jornal a ter boa aceitação em nosso meio, como prova a sua tiragem sempre crescente, mas, dias atrás, um amigo nosso sugeriu que ataquessemos o Govêrno [sic] em linguagem forte e incisiva. Respondemoslhes que não era esse o nosso lema, pois não queremos mover campanha pessoal contra ninguém, nem dirigir ataques sistemáticos contra nenhuma autoridade. Criticamos atos da administração estadual ou municipal somente com o propósito de bem servir à coletividade e não para fazer demagogia ou adquirir cartaz à custa de sensacionalismos (ECOS, 1952c, p. 3).

Ao tempo, a redação de $A$ Luta também condenou a calúnia e a mentira nos leads jornalísticos, por considerar esse tipo de prática como própria do jornalismo mercenário, ou seja, aquele jornalismo que ganha dinheiro usando recursos torpes. Com isso, o jornal reiterava seu papel na imprensa piauiense como órgão apartidário e informativo e atribuía para si a função de orientar a opinião pública e promover o bem comum.

De acordo com Ribeiro (2007), para a implantação desse modelo de jornalismo, houve várias racionalizações forjadas pelos jornalistas por meio da produção de um discurso dominante que enfatizava os conceitos de objetividade e de missão da imprensa como elementos fundamentais para a construção da autoimagem do jornalismo e do seu papel na imprensa nos anos cinquenta do século XX.

À época, considerava-se que o papel do jornalista era informar, zelar pela comunidade, formular críticas e informar/formar a opinião pública a partir de um conjunto de regras e normas de comportamentos éticos, e a técnica aparecia como elemento central da objetividade e verdade da notícia. Segundo Lima (2014), cada um dos jornais de Teresina dedicou parte do seu tempo para a produção de textos que tratavam sobre o papel da imprensa e do jornalista e seu compromisso com a coletividade. Os jornais destacavam a necessidade de rever os princípios jornalísticos que regiam a produção discursiva da imprensa local, principalmente porque a maioria dos jornais ainda pertencia aos políticos e se colocava a serviço dos seus partidos na década de 1950. 
A par das discussões, a redação de $A$ Luta não se furtou a contemplar o tema. Até porque os seus redatores viajavam ao Rio de Janeiro para atuar como colaboradores de jornais cariocas ou eram correspondentes na metrópole. Portanto, os redatores acompanhavam de perto as mudanças e as discussões pertinentes à implantação do modelo de jornalismo moderno no Brasil e pretendiam se apresentar discursivamente como tal.

\section{Considerações finais}

De junho a setembro de 1952, o jornal A Luta buscou introduzir elementos do jornalismo moderno na sua redação e apresentar-se como tal para o público leitor, por meio do discurso autorreferencial. A estratégia foi utilizada pelos jornalistas de A Luta para reforçar/excluir valores, competências e regras que pretendiam imputar para a redação do jornal, com o objetivo de defender a imparcialidade da linha editorial frente aos interesses políticos e partidários. Dessa maneira, os profissionais apresentaram o órgão como independente, informativo e noticioso, tendo como lema servir a coletividade e condenar o erro dos homens públicos involuntariamente da sua filiação partidária.

A publicação insere-se em um período em que a imprensa passava por transição e muitos periódicos ainda serviam de instrumentos dos partidos e/ou políticos que os mantinham financeiramente. Nesse contexto, a redação de $A$ Luta não deixou de refletir sobre o fazer jornalístico, especialmente, quando criticava suas práticas e afirmava que os jornalistas deveriam escrever suas matérias com responsabilidade, a fim de fazer uma imprensa "sadia", "moralizadora" e "honesta". Tais princípios eram defendidos pelo novo jornalismo, que condenava o emprego de xingamentos, comentários pessoais, verrinas, e exigia restrições formais tanto para a linguagem quanto para a estruturação do texto.

Nessa perspectiva, a redação e a direção de $A$ Luta defenderam como regra da produção noticiosa a publicação de textos com uma linguagem decente e comedida, afiançaram a imparcialidade da linha editorial por meio dos termos "informativo", "noticioso", "sadio" e "honesto", sem que, para isso, abdicassem do direito de opinar sobre a vida políticaadministrativa do Piauí em 1952. 


\section{Referências}

A DIREÇÃO. Conversa. A Luta, Teresina, ano 1, n. 4, p. 8, 20 jul. 1952.

A LUTA. Jornal maior. A Luta, Teresina, ano 1, n. 5, p. 3, 27 jul. 1952.

ASSUNÇÃO, Rosângela. Governo Rocha Furtado: uma administração conturbada. In: LIMA, Solimar Oliveira; ASSUNÇÃO, Rosângela. (org.). Governos e políticas públicas: a experiência do Piauí. Rio de Janeiro: Booklink, 2009. p. 37-79.

CONVERSA. A Luta, Teresina, ano 1, n. 2, p. 1, 6 jul. 1952.

CORREIO DE “A LUTA”. A Luta, Teresina, ano 1, n. 3, p. 3, 13 jul. 1952a.

CORREIO DE “A LUTA”. A Luta, Teresina, ano 1, n. 4, p. 2, 20 jul. 1952 b.

CRESTANI, Luciana Maria. A participação do leitor como co-enunciador em jornais impressos e on-line: abordagem à luz da enunciação. Vivências: Revista Eletrônica de Extensão da URI, Erechim, 2010.2 Disponível em: http://www2.reitoria.uri.br/ vivencias/Numero_009/artigos/artigos_vivencias_09/n9_3.pdf. Acesso em: 20 abr. 2019.

ECOS. A Luta, Teresina, ano I, n. 3, p. 3, 13 jul. 1952a.

ECOS. A Luta, Teresina, ano I, n. 8, 23 ago. 1952b.

ECOS. A Luta, Teresina, ano I, n. 10, p. 3, 7 set. 1952c.

FAUSTO NETO, Antônio. Mutações no discurso jornalístico: da "construção da realidade" a "realidade da construção". In: CONGRESSO BRASILEIRO DE CIÊNCIAS DA

COMUNICAÇÃO, 29., 2006, Brasília. Anais [...]. São Paulo: Intercom, 2006. Disponível em: http://www.intercom.org.br/papers/nacionais/2006/resumos/R1804-1.pdf. Acesso em: 25 mar. 2019.

FOUCAULT, Michel. A ordem do discurso. São Paulo: Loyola, 1999.

FOUCAULT, Michel. Arqueologia do saber. Rio de Janeiro: Forense Universitária, 2010.

LIMA, Lino Correa. O jornalista. A Luta, Teresina, ano 1, n. 2 , p. 4, 6 jul. 1952.

LIMA, Nilsângela Cardoso. Relações de poder e práticas jornalísticas em O Dia, A Cidade e Jornal do Piauí (1951-1954). 2014. Tese (Doutorado em Ciências da Comunicação) Universidade do Vale do Rio dos Sinos, São Leopoldo, 2014. 
LOPES, Fernanda Lima. Auto-referência, discurso e autoridade jornalística. Biblioteca Online de Ciências da Comunicação, Covilhã, p. 1-14, 2007. Disponível em: http://www.bocc.ubi.pt/pag/lopes-fernanda-auto-referencia-discurso.pdf. Acesso em: 08 jan. 2019.

LUCA, Tânia Regina. de. A grande imprensa na primeira metade do século XX. In: MARTINS, Ana Luiza; LUCA, Tânia Regina de (org.). História da imprensa no Brasil. 2. ed. São Paulo: Contexto, 2011. p. 149-178.

MARTINS, Ana Luiza. Imprensa em tempo de império. In: MARTINS, Ana Luiza; LUCA, Tânia Regina de. História da imprensa no Brasil. 2. ed. São Paulo: Contexto, 2011. p. 45-82

MELO, José Marques de. Sociologia da imprensa brasileira. Petrópolis: Vozes, 1973.

MELO, José Marques de. A opinião no jornalismo brasileiro. Petropólis: Vozes, 1985.

PINHEIRO FILHO, Celso. História da imprensa no Piauí. Teresina: Zodíaco, 1996.

PROGRAMA. A Luta, Teresina, ano I, n. 1, p. 1, 29 jun. 1952.

RÊGO, Ana Regina. Imprensa piauiense: atuação política no século XIX. Teresina: Fundação Cultural Monsenhor Chaves, 2001.

RÊGO, Ana Regina. Imprensa piauiense: atuação política no século XIX. In: ENCONTRO NACIONAL DA REDE ALFREDO DE CARVALHO, 1., 2003, Rio de Janeiro. Anais [...]. Porto Alegre: Universidade Federal do Rio Grande do Sul, 2003. Disponível em: http://www.ufrgs.br/alcar/encontros-nacionais-1/encontros-nacionais/1o-encontro-20031/imprensa\%20piauiense.doc. Acesso em: 20 ago. 2018.

RIBEIRO, Ana Paula Goulart. Jornalismo, literatura e política: a modernização da imprensa carioca nos anos 1950. In: Estudos Históricos, Rio de Janeiro, n. 31, 2003, p. 147-160. Disponível em: http://bibliotecadigital.fgv.br/ojs/index.php/reh/article/view/2186/1325. Acesso em 20 ago. 2018.

RIBEIRO, Ana Paula Goulart. Imprensa e história no Rio de Janeiro dos anos 1950. Rio de Janeiro: E-papers, 2007.

TRAQUINA, Nelson. Teorias do jornalismo - porque as notícias são como são. 2. ed. Florianópolis: Insular, 2005. v.1.

TRAQUINA, Nelson. Teorias do jornalismo. A tribo jornalística - uma comunidade interpretativa transnacional. Florianópolis: Insular, 2008.

VIDA DOS PARTIDOS. A Luta, Teresina, ano I, n. 3, p. 8, 13 jul. 1952. 
Submetido em: 04.04.2020

Aprovado em: 19.06.2021 